\title{
Analisis Tingkat Pengetahuan, Body Image dan Pola Makan terhadap Status Gizi Remaja Putri
}

\author{
Norma Jeepi Margiyanti \\ Prodi DIII Kebidanan, Institut Kesehatan Mitra Bunda \\ Email: normajeepi02@gmail.com
}

Submitted: 30/12/2020 Accepted:21/01/2021 Published: 06/03/2021

\begin{abstract}
Nutritional problems in adolescents arise due to incorrect nutritional behavior, namely the imbalance between the consumption of nutrients and the adequacy of recommended nutrients. The main nutritional problems in adolescents are micronutrients deficiency, especially iron deficiency anemia, as well as malnutrition problems, both malnutrition and short stature and more nutrition to obesity with co-morbidity which are both often related to wrong behavior / diet, namely the imbalance between nutritional consumption and nutritional adequacy recommended. The purpose of this research is to find out the relationship of knowledge, body image, and diet with the nutritional status of young women. This research method uses a descriptive approach to correlation, namely research conducted to look at the relationship between diet and nutritional status of young women. The results of the study were given $P$ value $=0.016$ which means there is a relationship between diet and nutritional status of young women. There is a relationship between the body image and the nutritional status of young women with P Value 0.000 and there is no relationship between the level of knowledge and the nutritional status of young women and $P$ value of 0.083. Advice to stakeholders in order to be able to carry out a thorough socialization of nutrition in adolescents through promotional activities, increasing the capacity of health workers on adolescent nutrition and improving the implementation of the Youth Care Health Services (PKRR) program.
\end{abstract}

Keywords: diet, nutritional status, teen nutrition

\begin{abstract}
Abstrak
Masalah gizi yang muncul pada masa remaja disebabkan oleh pola konsumsi yang tidak baik, yakni ketidakseimbangan antara konsumsi (intake) dengan kecukupan gizi yang dianjurkan. Masalah nutrisi utama pada remaja adalah defisiensi mikronutrien, khususnya anemia defisiensi zatbesi, serta masalah malnutrisi, baik gizi kurang dan perawakan pendek maupun gizi lebih sampai obesitas dengan ko-morbiditasnya yang keduanya seringkali berkaitan dengan perilaku/ pola makan salah, yaitu ketidakseimbangan antara konsumsi gizi dengan kecukupan gizi yang dianjurkan. Tujuan dari prilakukannya penelitian ini adalah untuk mengetahui hubungan pengetahuna, Body Image, dan Pola makan dengan status gizi remaja putri. Metode penelitian ini menggunakan pendekatan deskriptif korelasi yaitu penelitian yang dilakukan untuk melihat hubungan antara pola makan dengan status gizi remaja putri. Hasil penelitian didapatkan $P$ value $=0.016$ yang artinya terdapat hubungan antara pola makan dengan status gizi remaja putri. Terdapat hubungan antara body image dengan status gizi remaja putrid dengan $\mathrm{P}$ Value 0.000 dan tidak ada hubungan antara tingkat pengetahuan dengan status gizi remaja putrid dengan $\mathrm{P}$ value 0.083. Saran kepada pemangku kepentingan agar dapat melaksanakan sosialisasi secara menyeluruh tentang gizi pada remaja melalui kegiatan promosi, peningkatan kapasitas petugas kesehatan tentang gizi remaja dan peningkatan pelaksanaan program Pelayanan Kesehatan Peduli Remaja (PKRR).
\end{abstract}

Kata kunci: gizi remaja, pola makan, status gizi

\section{PENDAHULUAN}

Remaja atau adolescent merupakan suatu masa peralihan dari masa kanakkanan menuju masa dewasa, dimana pada masa ini seorang anak akan mengalami pertumbuhan dan perkembangan untuk mencapai kematangan mental, emosional, sosial dan fisik. Masa remajamenurut WHO 
adalahantara $10 \quad-24$ tahun, sedangkan menurut BKKBN masa remaja berlangsung pada umur 10-24 tahun dan belum menikah.

Masa remaja merupakan masa yang sangat penting dari proses pertumbuhan dan perkembangan manusia. Kondisi seseorang pada masa dewasa banyak ditentukan oleh keadaan gizi dan kesehatan pada masa remaja. Oleh karena itu status gizi dan kesehatan merupakan factor penentu kualitas remaja.

Tingkat pertumbuhan paling cepat terdapat pada usia anak sekolah hal ini seiring bersama dengan datangnya masa remaja. Pada tahap pertumbuhan yang demikian anak mendapatkan pengalaman makan dan juga makanan yang diperoleh dari lingkungan keluarga dan lingkungan diluar rumah. Remaja yang mendapat konsumsi pangan yang memenuhi kecukupan gizi sejak masa anak-anak akan memiliki perkembangan tubuh yang baik, memiliki postur tubuh yang lurus, otot yang kuat dan cadangan lemak yang cukup.

Masalah gizi yang muncul pada masa remaja disebabkan oleh pola konsumsi yang tidak baik, yakni ketidakseimbangan antara konsumsi (intake) dengan kecukupan gizi yang dianjurkan. Tidak terpenuhinya kebutuhan nutrisi pada masa ini dapat berakibat terlambatnya pematangan seksual dan hambatan pertumbuhan linear. Pada masa ini pula nutrisi penting untuk mencegah terjadinya penyakit kronik yang terkait nutrisi pada masa dewasa kelak, seperti penyakit kardiovaskular, diabetes, kanker dan osteoporosis.

Masalah gizi yang sering terjadi pada remaja putrid adalah gizi kurang (under weight), gizi lebih (over weight) dan anemia. Gizi kurang terjadi karena jumlah konsumsi energi dan zat-zat gizi lain tidak memenuhi kebutuhan tubuh. Namun pada remaja putri, kejadian gizi kurang umumnya dikarenakan remaja putri membatasi jumlah makanan yang dimakannya.
Sedangkan kejadian gizi lebih pada remaja disebabkan karena kebiasaan makan yang kurang baik sehingga jumlah masukan energi (energy intake) kedalam tubuh berlebih, dan kejadian anemia pada remaja dikarenakan rendahnya asupan zatbesi. Sebelum masa remaja, kebutuhan nutrisi anak lelaki dan anak perempuan tidak dibedakan, tetapi pada masa remaja terjadi perubahan biologik dan fisiologik tubuh yang spesifik sesuai gender (gender specific) sehingga kebutuhan nutrienpun menjadi berlainan. Seorang remaja putri membutuhkan zat besi lebih banyak dibandingkan dengan remaja laki-laki karena mengalami menstruasi setiap bulan.

Remaja putri lebih beresiko terkena anemia selain karena kebiasaan membatasi jumlah makanan yang dikonsumsi khususnya pada sumber pangan hewani juga dikarenakan menstruasi dan meningkatnya kebutuhan zatbesi selama growth spurt. Status gizi remaja dipengaruhi oleh beberapa faktor diantaranya faktor ekonomi, tingkat pendidikan, faktor budaya seperti kebiasaan makan, body image dan lain sebagainya. Oleh karena itu berdasarkan faktor-faktor tersebut akan dibahas lebih lanjut tentang pengetahuan gizi, body image, pola makan dan status gizi.

\section{METODE PENELITIAN}

Penelitian ini menggunakan desain penelitian deskriptif korelasi dengan pendekatan cross secsional yaitu penelitian yang dilakukan untuk melihat hubungan antara variabel satu dengan variabel lain yang dilakukan pada suatu saat. Penelitian ini bertujuan untuk menganalisis hubungan antara Pengetahuan, body image dan Pola makan terhadap status gizi remaja putri. Sampel dari penelitian ini adalah remaja putri Prodi D-III Kebidanan STIKes Mitra Bunda sebanyak 99 responden. Pengambilan data menggunakan kuesioner yang selanjutnya dianalisis menggunakan Chi-Square. 


\section{HASIL DAN PEMBAHASAN}

Berdasarkan penelitian yang telah dilakukan tentang Analisis Tentang Pengetahuan, body image dan Pola Makan Terhadap Status Gizi Remaja Putri di STIKes Mitra Bunda Persada dengan sampel sebanyak 99 mahasiswa Prodi Diploma III Kebidanan didapatkan hasil sebagai berikut:

\section{Analisis Univariat}

a. Tingkat Pengetahuan

Tabel 1 Distribusi FrekuensiTingkat Pengetahuan

\begin{tabular}{ccc}
\hline Pengetahuan & (f) & $(\boldsymbol{\%})$ \\
\hline Baik & 35 & 35.4 \\
Cukup & 48 & 48.5 \\
Kurang & 16 & 16.2 \\
Total & 99 & 100.0 \\
\hline
\end{tabular}

Berdasarkan table 1 dapat diketahui bahwa sebagian besar responden memiliki tingkat pengetahuan cukup sebanyak 48 orang $(48.5 \%)$

b. Body Image

\section{Tabel 2 Distribusi Frekuensi Body \\ Image}

\begin{tabular}{ccc}
\hline Body Image & $(\mathbf{f})$ & $(\boldsymbol{\%})$ \\
\hline Positive & 60 & 60.6 \\
Negative & 39 & 39.4 \\
orang & & $(60.6 \%)$
\end{tabular}

\begin{tabular}{lll} 
Total & 99 & 100.0 \\
\hline
\end{tabular}

Berdasarkan table 2 dapat diketahui bahwa mayoritas responden memiliki Body Image yang positive sebanyak 60 orang $(60.6 \%)$

c. Pola Makan

Tabel 3 Distribusi Frekuensi Pola Makan

\begin{tabular}{ccc}
\hline Pola Makan & $(\mathbf{f})$ & $\mathbf{( \% )}$ \\
\hline Baik & 41 & 41.4 \\
TidakBaik & 58 & 58.6 \\
Total & 99 & 100.0 \\
\hline
\end{tabular}

Berdasarkan table 3 dapat diketahui bahwa sebagian besar responden memiliki pola makan tidak baik sebanyak 58 orang $(58.6 \%)$

d. Status Gizi

Tabel 4 Distribusi Frekuensi Pola Makan

\begin{tabular}{ccc}
\hline Status Gizi & $(\mathbf{f})$ & $\mathbf{( \% )}$ \\
\hline Under Nutrition & 17 & 17.2 \\
Balanced Nutrition & 60 & 60.6 \\
Over Nutrition & 8 & 8.1 \\
Obesitas & 14 & 14.1 \\
Total & 99 & 100.0 \\
\hline
\end{tabular}

Berdasarkan table 4 dapat diketahui bahwa mayoritas responden memiliki status gizi pada level balanced nutrition sebanyak 60

\section{Analisis Bivariat}

Hubungan Tingkat Pengetahuan dengan Status Gizi

Tabel 5 Hubungan Tingkat Pengetahuan dengan Status Gizi

\begin{tabular}{ccccccc}
\hline No & Pengetahuan & $\begin{array}{c}\text { Under } \\
\text { Nutrition }\end{array}$ & $\begin{array}{c}\text { Balanced } \\
\text { Nutrition }\end{array}$ & $\begin{array}{c}\text { Over } \\
\text { Nutrition }\end{array}$ & Obesitas & Total \\
\hline 1 & Baik & 2 & 21 & 6 & 6 & 35 \\
2 & Cukup & 12 & 30 & 1 & 5 & 48 \\
3 & Kurang & 3 & 9 & 1 & 3 & 16 \\
& Total & 17 & 60 & 8 & 14 & 99 \\
\hline
\end{tabular}


Berdasarkan table 5 dapat diketahui bahwa responden yang memiliki status gizi balanced nutrition memiliki tingkat pengetahuan cukup yaitu sebanyak 30 reponden. Hasil hitung menggunakan SPSS didapatkan Chi Square $=11.186$ dan $\mathrm{P}$ Value lebih besar dari alfa yakni 0.083 yang artinya tidak ada hubungan antara tingkat pengetahuan dengan status gizi remaja putri.

Analisis korelasi yang dilakukan pada variable Tingkat Pengetahuan dengan Status Gizi remaja putri didapatkan hasil $\mathrm{P}$ value lebih besar dari alfa yakni 0.083 , yang artinya tidak ada hubungan antara tingkat pengetahuan dengan status gizi remaja putri.

Hasil penelitian ini berbanding terbalik dengan penelitian (Florence, 2017) yang berjudul Hubungan Pengetahuan Gizi Dan Pola Konsumsi Dengan Status Gizi Pada Mahasiswa TPB Sekolah Bisnis Dan Manajemen Institut Teknologi Bandung menyatakan bahwa ada hubungan antara pengetahuan gizi dengan status gizi pada mahasiswa TPB di Sekolah Bisnis seharian. dan Manajemen Institut Teknologi Bandung dengan $\mathrm{X}^{2}$ hitung 35,045 > $\mathrm{X}^{2}$ tabel 30,98.

Menurut Notoatmodjo (2007) terdapat beberapa faktor yang mempengaruhi pengetahuan seseorang, yaitu : Pendidikan, Informasi, Sosial budaya dan ekonomi, Lingkungan, Pengalaman, Usia.

pengetahuan tentang gizi sangat mempengaruhi seseorang dalam memenuhi kebutuhannya. kedalaman dan keluasan pengetahuan tentang gizi akan menuntun seseorang dalam pemilihan jenis makanan yang akan mengkonsumsi baik dari segi kualitas, variasi maupun cara penyajian pangan yang diselaraskan dengan konsep pangan. misalnya, konsep pangan yang berkaitan dengan kebutuhan fisik. apakah makan asal kenyang atau untuk memenuhi kebutuhan tubuh (almatsier, 2011) dimungkinkan karena banyaknya faktor yang mempengaruhi pengetahuan seseorang membuat informasi yang diterima dibangku kuliah tentang gizi reproduksi sulit untuk diterapkan didalam kehidupan ke

Hubungan Body Image dengan Status Gizi

Tabel 6 Hubungan Body Image dengan Status Gizi

\begin{tabular}{llccccc}
\hline No & Body Image & $\begin{array}{c}\text { Under } \\
\text { Nutrition }\end{array}$ & $\begin{array}{c}\text { Balanced } \\
\text { Nutrition }\end{array}$ & $\begin{array}{c}\text { Over } \\
\text { Nutrition }\end{array}$ & Obesitas & Total \\
\hline 1 & Positive & 17 & 41 & 1 & 1 & 60 \\
2 & Negative & 0 & 19 & 7 & 13 & 39 \\
& Total & 17 & 60 & 8 & 14 & 99 \\
\hline
\end{tabular}

Berdasarkan table 6 dapat diketahui bahwa responden yang memiliki status gizi balanced nutrition memiliki body image positive yaitu sebanyak 41 reponden. Hasil hitung menggunakan SPSS didapatkan Chi Square $=37.006$ dan $\mathrm{P}$ Value lebih kecil dari alfa yakni 0.000 yang artinya ada hubungan antara body image dengan status gizi remaja putri.

Analisis korelasi yang dilakukan pada variable Body Image dengan Status Gizi remaja putri didapatkan hasil $\mathrm{P}$ value lebih kecil dari alfa yakni 0.00 yang artinya ada hubungan antara 
body image dengan status gizi remaja putri.

Hasil penelitian ini sejalan dengan penelitian (Maracilu, 2015) yang berjudul Hubungan Body Image dengan Status Gizi dan Ktivitas Fisik Pada Siswa-Siswa Sekolah Menengah Atas di Aceh dan Aceh Besar dengan hasil Hasil uji analisis Chi-Square untuk variabel body image dengan status gizi yaitu ( $p=0,039)$ sehingga menunjukkan terdapat hubungan body image terhadap status gizi

Body image adalah gambaran mental atau sikap seseorang terhadap

Hal-hal yang menyebabkan remaja putri tidak menerima kondisi fisiknya seperti: tinggi badan, bentuk badan, jerawat. Remaja putri sangat sensitif terhadap penampilan dirinya dan bagaimana kondisi wajahnya, apakah orang lain menyukai wajahnya serta selalu mempersepsikan seperti apa tubuhnya dan apa yang diinginkan dari tubuhnya.

Berdasarkan beberapa pendapat di atas, dapat disimpulkan bahwa body image citra tubuh adalah pemikiran atau konsep tentang fisik berupa penilaian diri yang subyektif, evaluasi terhadap diri berdasarkan bagaimana penilaian orang lain terhadap dirinya, yang berfungsi sebagai salah satu bentuk control sosial. bentuk dan ukuran tubuhnya, bagaimana seseorang mempersepsi dan memberikan penilaian atas apa yang dia pikirkan dan rasakan terhadap ukuran dan bentuk tubuhnya, dan bagaimana penilaian orang lain terhadap dirinya. Sebenarnya, apa yang dia pikirkan dan rasakan, belum tentu benar-benar merepresentasikan keadaan yang aktual, namun lebih merupakan hasil penilaian diri yang subyektif. Citra tubuh pada umumnya berhubungan dengan remaja putri daripada remaja pria, remaja putri cenderung untuk memperhatikan penampilan fisik (Mappiare, 1982)

Selain itu termasuk di dalamnya kesadaran individu dan bagaimana penerimaan terhadap kondisi fisik, yang kemudian akan memicu perasaan senang atau tidak senang terhadap tubuhnya, sehingga mempengaruhi proses berfikir, perasaan, keinginan, nilai maupun perilakunya. Body Image selalu berubah-ubah karena akan selalu berkembang selama hidup melalui interaksi dengan orang lain.

Persepsi diri tentang body image atau citra tubuh dapat mempengaruhi pola konsumsi seseorang, dimana pola konsumsi sehari-hari berkontribusi dalam pemenuhan nutrian harian yang dapat berdampak pada status gizi seseorang.

Hubungan Pola Makan dengan Status Gizi Tabel 7 Hubungan Pola Makan dengan Status Gizi

\begin{tabular}{llccccc}
\hline No & Pola Makan & $\begin{array}{c}\text { Under } \\
\text { Nutrition }\end{array}$ & $\begin{array}{c}\text { Balanced } \\
\text { Nutrition }\end{array}$ & $\begin{array}{c}\text { Over } \\
\text { Nutrition }\end{array}$ & Obesitas & Total \\
\hline 1 & Baik & 7 & 31 & 2 & 1 & 41 \\
2 & Tidak Baik & 10 & 29 & 6 & 13 & 38 \\
& Total & 17 & 60 & 8 & 14 & 99 \\
\hline
\end{tabular}

Berdasarkan table 7 dapat diketahui bahwa responden yang memiliki status gizi balanced nutrition memiliki pola makan baik yaitu sebanyak 31 reponden. Hasil hitung menggunakan SPSS didapatkan Chi Square $=10.265$ dan $\mathrm{P}$ Value lebih kecil dari alfa yakni 0.016 yang artinya ada 
hubungan antara pola makan dengan status gizi remaja putri

Analisis korelasi yang dilakukan pada variable pola makan dengan status gizi remaja putri didapatkan hasil $\mathrm{P}$ value lebih kecil dari alfa yakni 0.016 yang artinya ada hubungan antara pola makan dengan status gizi remaja putri.

Pola konsumsi makan adalah kebiasaan makan yang meliputi jumlah, frekuensi dan jenis atau macam makanan. Penentuan pola konsumsi makan harus memperhatikan nilai gizi makana dan kecukupan zat gizi yang dianjurkan. (Supariasa, dkk, 2002).

Kebutuhan akan makan tidak hanya keinginan untuk mengatasi rasa lapar, tetapi selain itu ada kebutuhan fisiologis tubuh dan psikologis yang mempengaruhi. Pola konsumsi pangan merupakan faktor yang sangat berpengaruh terhadap status gizi remaja. Pola konsumsi mencakup berbagai jenis pangan dan jumlah serta frekuensi pangan yang dikonsumsi yang secara kuantitas seluruhnya menentukan ukuran tinggi rendahnya pangan yang dikonsumsi. Dibandingkan kategori usia lainnya, diet yang tidak adekuat adalah masalah yang sering dialami remaja putri. Gizi tidak adekuat akan menimbulkan masalah kesehatan yang akan mengikuti sepanjang kehidupan (Soekirman, 2006).

Kekurangan gizi dalam masa remaja dapat disebabkan oleh berbagai faktor termasuk emosi yang tidak stabil, keinginan untuk menjadi kurus yang tidaktepat, dan ketidakstabilan dalam gaya hidup dan lingkungan sosial secara umum (Soekirman, 2006).

Beberapa perilaku spesifik yang secara umum dipercay amenyebabkan masalah gizi pada remaja putri adalah: (1). Kurang didampingi ketika mengkonsumsi makanan tertentu, (2). Kurangnya perhatian dalam memilih makanan di luar rumah, (3). Kurangnya waktu uantuk mengkonsumsi secara teratur, (4). Melewatkan waktu makan satu kali atau lebih setiap hari, (5). Mulai mengkonsumsi alkohol, (6). Pemilihan makanan selingan yang kurang tepat, (7). Perhatian terhadap makanan tertentu yang menyebabkan jerawat, (8). Takut mengalami obesitas, (9). Tidak mau minum susu. Kebiasaan makan cemilan diluar jam makansering dimiliki remaja putrid sebagai gaya hidup. Selain itu duduk berlama-lama sambil makan cemilan yang tinggi kalori dan lemak, serta makanan rendah gizi memicu terjadinya kelebihan berat badan pada remaja. Kebiasaan makan seseorang berdampak terhadap asupan nutrisi yang masuk kedalam tubuh, hal itu dapat menentukan status gizi seseorang.

\section{SIMPULAN}

Berdasarkan hasil penelitian Analisis Tingkat Pengetahuan, Body Image dan Pola Makan terhadap Status Gizi Remaja Putri dapat disimpulkan sebagai berikut: Terdapat hubungan antara pola makan dengan status gizi remaja putri dengan $\mathrm{P}$ Value 0.016. Terdapat hubungan antara body image dengan status gizi remaja putri dengan P Value 0.000. Tidak ada hubungan antara tingkat pengetahuan dengan status gizi remaja putri dengan $\mathrm{P}$ value 0.083

\section{SARAN}

Agar dapat melaksanakan sosialisasi secara menyeluruh tentang gizi pada remaja melalui kegiatan promosi, peningkatan kapasitas petugas kesehatan tentang gizi remaja dan peningkatan pelaksanaan program Pelayanan Kesehatan Peduli Remaja (PKRR).

\section{DAFTAR PUSTAKA}

Departemen Kesehatan RI. 2007. Pedoman Pengukuran Dan Pemeriksaan. Depkes RI. Jakarta.

Departemen Kesehatan RI. 2014. Pedoman Umum Gizi Seimbang. Depkes RI. Jakarta. 
Florence.2017.Hubungan Pengetahuan Gizi dan Pola Konsumsi Dengan Status Gizi Pada Mahasiswa TPB Sekolah Bisnis dan Menejemen Institut Teknologi Bandung

Hardinsyah. 2017. Ilmu Gizi Teori\& Aplikasi.EGC. Jakarta Irianto, K. 2014. Gizi Seimbang dalam Kesehatan Reproduksi. 1st ed. Alfabeta. Bandung

Maracilu, Cut Nabela. 2015. Hubungan Body Image Terhadap Status Gizi dan Aktivitas Fisik pada Siswa Siswi Sekolah Menengah Atas di Banda Aceh dan Aceh Besar. ETD Unsyiah. https://etd.unsyiah.ac.id/index.php?p =show_detail\&id=19072
Notoatmodjo, S. 2005. Metodologi Penelitian Kesehatan EdisiRevisi. PT. Rineka Cipta. Jakarta

Sugiyono. 2009. Statistika Untuk Penelitian. Alfabeta. Bandung

Sugiyono. 2007. Metode Penelitian Kuantitatif Kualitatif dan R\&D. Alfabeta. Bandung

Suhardjo. 2006. Berbagai Cara Pendidikan Gizi. BumiAksara.Jakarta

Supariasa. 2016. Penilaian Status Gizi. EGC. Jakarta

Soekirman. 2006. Hidup Sehat Gizi Seimbang Dalam Siklus Kehidupan Manusia. Primamedia Pustaka. Jakarta 